\title{
A working model for preventing crop damage caused by increasing goose populations in Sweden
}

\author{
En arbetsmodell för att förebygga skador på gröda orsakade av växande \\ gåspopulationer i Sverige
}

MIKAEL HAKE, JOHAN MÅNSSON \& ANNE WIBERG

\begin{abstract}
The populations of several goose species have increased rapidly in Sweden, as well as in other parts of Europe, particularly during the last decade. As a consequence, the damage caused by the birds to commercially grown agricultural crops has increased. In 2008, the Swedish government paid about 500,000 $€$ for preventive measures and subsidies to affected farmers. To reduce the economical losses and conflicts between the geese and humans, it is necessary to establish and maintain communication between the different interest groups and to implement measures to prevent the damage. We here present a working model, which is currently used for reducing humangeese conflicts in Sweden. The working model is based

on the initiation of management groups which may develop a management plan on the basis of information collected about the behaviour of the birds and the temporal and spatial variations of crop damage caused within local areas. We give an overview of the preventive measures taken within these plans and discuss how effective they may be to reduce conflicts between geese and humans.

Mikael Hake, Johan Månsson and Anne Wiberg, Wildlife Damage Centre, Grimsö Wildlife Research Station, Department of Ecology, Swedish University of Agricultural Sciences, SE-730 91 Riddarhyttan, Sweden. E-mail:Mikael.Hake@ekol.slu.se.
\end{abstract}

\section{Introduction}

The populations of several European goose species have increased considerably during the last decades. Between 1995 and 2008, the number of wintering geese in north-western Europe increased by $24 \%$, from about $3,500,000$ to $4,300,000$ (Fox et al. 2010). The grazing and trampling by the geese may have a large impact on vegetation, including commercially grown agricultural crops (McIvor \& Conover 1994, Zacheis et al. 2001, Jefferies et al. 2004). As a consequence, the aggregation of grazing geese within farmland may cause conflicts between the birds and humans, particularly farmers (Lorenzen \& Madsen 1986, Summers 1990). The aggregations mainly occur at staging sites during migration, at breeding colonies or when non-breeding birds flock at attractive foraging sites (Zacheis et al. 2001, Samelius \& Alisauskas 2009).

Also in Sweden, the populations of several goose species have increased rapidly, particularly during the last $10-15$ years. Annual national counts of geese have been conducted during autumn and winter since the late 1970s. These counts reveal that all goose species except the Bean Goose Anser fabalis and the Lesser White-fronted Goose Anser erythropus have increased since the surveys were introduced (Nilsson 2009). The Greylag Goose Anser anser has, for example, increased more than tenfold (from about 20,000 to 225,000 birds) during 1984-2009, and a similar pattern has been found for the Barnacle Goose Branta leucopsis (Nilsson 2009). Breeding populations of these two species have shown similar substantial increases. At the eutrophic lake Tåkern in south-central Sweden (Figure 1), the number of breeding Greylag Geese increased from about 100 to 1,000 pairs between 1996 and 2002 (Gezelius 2009), and the total number of breeding Barnacle Geese in Sweden has increased from very few to about 5,000 pairs during the last two decades (e.g. Feige et al. 2008).

The increase in population sizes of geese in Sweden has, like in the rest of Europe, brought an increase in crop damage in agricultural areas due to grazing birds, and this has resulted in conflicts between the birds and farmers. These conflicts are particularly pronounced for protected species, i.e. species which cannot be hunted during the periods 
when they cause the damage. The conflicts do not only result in financial losses for farmers affected, but may also lower the acceptance for geese and birds in general. As a consequence, landowners may be more reluctant to agree on setting off their land as reserves to protect vulnerable birds and other organisms (Gordon 2009). Thus, it is important that these conflicts are mitigated, as they may have severe consequences for both economics and the possibility to implement successful conservation measures.

In Sweden, the regulations for managing damage caused by protected wildlife were renewed in 1995 . The current regulations state that such damage should primarily be prevented by hunting. In situations where this is not possible, e.g. if the species

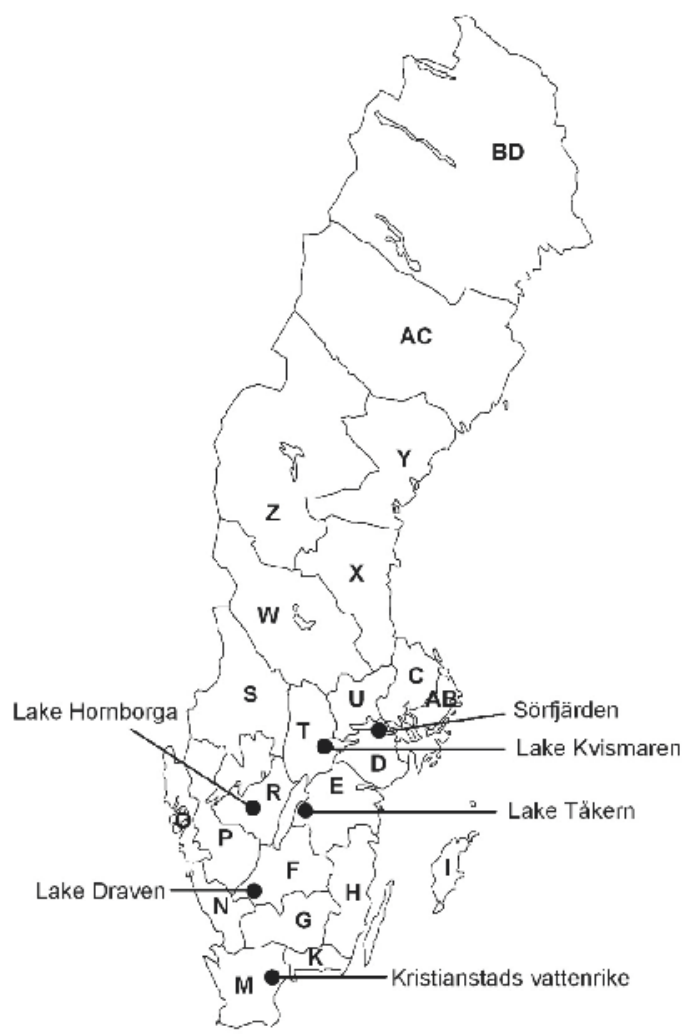

Figure 1. Map of Sweden showing the 21 counties and the location of six important breeding and staging sites for geese, cranes and whooper swans, mentioned in the text: lake Tåkern, lake Hornborga, lake Kvismaren, lake Draven, Sörfjärden and Kristianstads Vattenrike.

Karta över Sverige med de 21 länen och läget för sex viktiga områden för häckning och rastning för gäss, tranor och sångsvanar som nämns i texten: Tåkern, Hornborgasjön, Kvismaren, Draven, Sörfjärden och Kristianstads vattenrike.

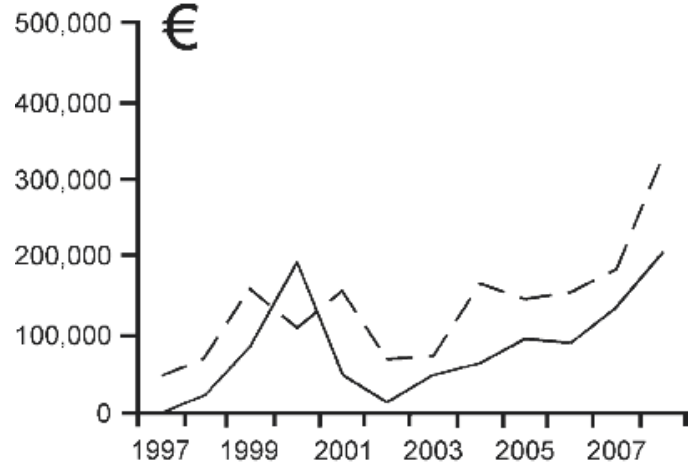

Figure 2. Amount of money paid for preventing and compensating crop damage caused by protected birds in Sweden 1997-2008. Dashed line $=$ subsidies for damage, solid line $=$ subsidies for preventive measures.

Belopp betalda för att förhindra och kompensera skördeskador orsakade av fridlysta fäglar i Sverige 1997-2008. Streckad linje $=$ ersättning för skador, heldragen linje $=$ ersättning för att förebygga skador.

causing damage are protected or if damage occurs within nature reserves or national parks, it should be prevented by other methods. If damage still occurs, the administration boards in the 21 counties (Figure 1) have the mandate to compensate affected stakeholders for their financial losses to mitigate the conflicts. The governmental subsidies for preventing damage on commercially grown crops and compensating farmers in agricultural areas have increased (Figure 2) as a result of the increasing populations of geese, Common Cranes Grus grus and Whooper Swans Cygnus cygnus. In 2008, the Swedish government paid about $200,000 €$ for preventing crop damage and an additional $300,000 €$ for subsidies to farmers affected by damage caused by grazing birds (Figure 2 ).

To promote the development of methods for preventing damage caused by protected wildlife and the conflicts this may bring, the government set off money to establish the organization Wildlife Damage Centre in 1995. The mission of this organization is to collect and distribute information among stakeholders concerned about how the damage caused by different kinds of protected animals vary in time and space and about the ecology and population development of the animals causing the damage (for further information, see: www.viltskadecenter.se). In this paper, we present a working model, developed by the Swedish Wildlife Damage Centre, which is used to prevent crop damage caused by protected bird species (including geese) in agricultural areas in Sweden. Examples of how 
the different measures included in this model may be used are provided and experiences of implementing the model are discussed.

\section{Methods and tools within the working model}

In Sweden, there are many agricultural areas where conflicts between grazing geese and farmers occur. These areas are mainly connected to breeding, staging and wintering sites of geese, Whooper Swans and Cranes in the southern parts of Sweden and along the coast of the Gulf of Bothnia further north. The conflict areas are sometimes related to nature reserves which provide good conditions for breeding and staging, e.g. lake Tåkern, lake Hornborga and lake Kvismaren (Figure 1) and in such areas it is, as mentioned earlier, particularly important to mitigate the conflicts.

Thus, the Wildlife Damage Centre has developed a working model, in which all interest groups may be involved in the collection of information needed, management decisions and implementation of management actions. This working model involves four major steps, which are taken in turn: (1) found a group with representatives from all stakeholders affected by the conflict, (2) collect information about the ecology and behaviour of the birds and the temporal and spatial variations of the damage they cause, (3) implement preventive measures, and (4) evaluate the measures taken so that the management strategy may be adaptively improved.

\section{Founding management groups}

Establish and maintain communication between all stakeholders by founding a group with representatives from all interest groups affected by the conflict. This group may be composed as shown in Figure 3 and should, for practical reasons, preferably not include more than 15 members. The group should have regular meetings to discuss and develop a management plan for preventing crop damage in the area of interest.

\section{Collecting information}

To develop a management plan, it is necessary to collect as much basic information as possible about the ecology and behaviour of the birds and the spatial and temporal variations of the damage they cause. This information is important for guiding where, when and how preventive measures should be implemented in the area of interest. Therefore, the next step should be to collect such

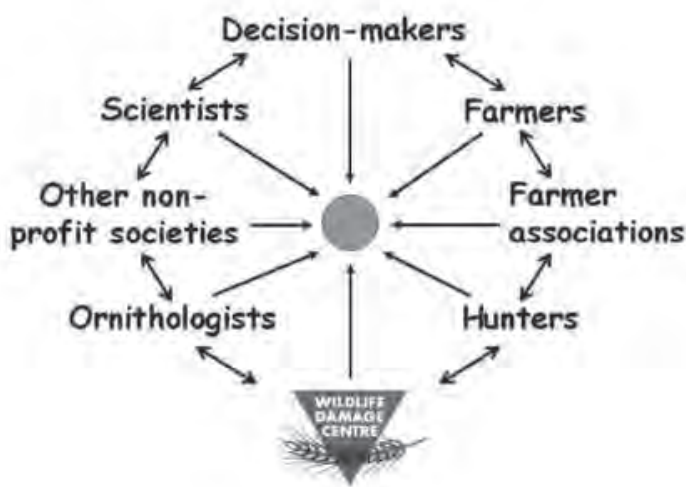

Figure 3. An example of how a management group may be composed. In Sweden, these groups have been founded on the initiative of managers and decision makers at the county administration boards.

Exempel på hur en förvaltningsgrupp kan vara sammansatt. I Sverige har dessa grupper bildats genom initiativ från länsadministrationen.

information by field surveys and by using already existing knowledge within the management group (e.g. information gained by local ornithologists and farmers).

\section{Implementing preventive measures}

Implementation of preventive measures involves four types of action.

Setting off accommodation fields. Set off accommodation fields where the birds are allowed to feed and may be undisturbed. These fields should be situated in areas the birds prefer to visit as revealed by results from field surveys or already existing local knowledge. If necessary, provide supplementary food in these areas to attract the birds during periods of the season when the risk of crop damage is particularly high.

Scaring of birds. Scare the birds away from vulnerable fields with a combination of scaring devices and protective hunting. If necessary, employ one or more persons who can help the farmers with scaring and hunting the birds.

Fencing. If necessary, put up fences to protect vulnerable crops on fields situated close to the breeding grounds of the geese. Preferably, specially designed fences to prevent crop damage caused by breeding and moulting geese should be used. These fences are about $1 \mathrm{~m}$ high and have a mesh size of maximum $50 \mathrm{~mm}$, at least at the bottom third, preventing small goslings from getting through.

Farming strategy. If possible, adopt a farming 
strategy that minimises the risk of crop damage caused by the geese. This may include many different actions, e.g. to grow crops that the birds do not prefer, growing vulnerable crops in areas less preferred by the birds, and growing varieties of crops that germinate and may be harvested earlier or later in the season. We know, for instance, that some crops are less attractive for the birds, e.g. rye and oats are less preferred than wheat and barley (Kjellander at al. 2002, Axelsson 2004). We also know that geese, as well as Common Cranes and Whooper Swans, are less prone to visit fields close to roads, houses or other devices connected to human activities (Kjellander et al. 2002, Wildlife Damage Centre, unpubl. data).

\section{Evaluating the measures taken}

Evaluate the effect of the preventive measures implemented by surveying the change in behaviour and numbers of birds, frequency of damage, costs and benefits and how people affected by the conflict experience the situation. The evaluation may be conducted at different spatial and temporal scales, e.g. from effects of single measures taken on specific fields to the total effects of all measures implemented within the working model.

\section{Results and discussion}

\section{Founding management groups}

Since 2002, management groups have been founded in 11 of the 21 counties in Sweden (Table 1, Figure 1). Crop damage occurs also within the other 10 counties, but so far to a lesser extent. The management groups have been founded on the initiative of the county administration boards, which are responsible for the regional wildlife management. Our general experience is that these groups are highly appreciated, as they promote communication and understanding between different interest groups such as decision-makers, farmers, ornithologists and hunters (Figure 3). Moreover, the local knowledge among members of these interest groups, e.g. about where and when crop damage occurs, population sizes and behaviour of birds and hunting strategies, is more easily picked up. In three counties, local management plans for preventing crop damage caused by geese, cranes and swans have been produced by the management groups (Table 1).

The founding of management groups has not only lead to increased communication among stakeholders but also provided a good working climate. The groups have also organised regular meetings to inform the public about their work and management decisions at least once a year. The importance of involving the public to enhance the acceptance of management decisions and the ability to respond more directly to management concerns has been highlighted for ecosystem management in general (Endter-Wada et al. 1998), large carnivore management (Skogen 2003), as well as planning of nature reserves (Jacobson \& McDuff 1998).

\section{Collecting information}

Following instructions worked out by established management groups, the administration boards in eight of the Swedish counties have initiated and conducted field studies of geese in local areas experiencing problems with grazing birds (Table 1). From these investigations, information about numbers, site fidelity and local movements of birds has been collected. This information has then been used as a basis for deciding which preventive measures that should be taken within the areas. For example, a thorough survey of numbers and spatial distribution of geese was made at lake Tåkern (Figure 1) during 2003-2004 (Axelsson 2004). As geese are normally traditional in their selection of feeding sites (for a review, see Vickery \& Gill 1999), this information was used to guide where and during which periods of the season accommodation fields should be set off in the agricultural areas surrounding the lake (Axelsson \& Modin 2006b). Similar surveys have been conducted at lake Kvismaren during 1996-1998 and lake Draven (Figure 1) during 2006-2008 (Wildlife Damage Centre, unpubl. data, Truvé 2006, 2008).

In some areas, local counts of the number of geese present during different parts of the year are made. At lake Tåkern, these counts have been conducted since 1970 (Gezelius 2009) and the information obtained is used to make predictions about how much damage one might expect during forthcoming years. For the same reason, information about breeding geese is collected through annual aerial surveys of the number of breeding geese in some "high-risk" areas, e.g. for the greylag goose in Kristianstads Vattenrike (Figure 1, Olofsson 2008).

To investigate where and when crop damage occurs, questionnaires have been sent out to farmers within local areas in three counties so far; at lake Tåkern, Sörfjärden and at the island of Öland in county $\mathrm{H}$ (Table 1, Figure 1). In addition, these questionnaires were designed to reveal information about how the farmers experience the conflicts with 
Table 1. Measures implemented within the working model to prevent conflicts between grazing birds and humans in the 21 counties during 2002-2009, i.e. since the first management group was founded in Sweden. Letters indicating the different counties refer to Figure 1. Y=Yes, -=No.

Atgärder som vidtagits inom arbetsmodellen för att förhindra konflikter mellan betande fåglar och människor $i$ de 21 länen 2002-2009, dvs. sedan den första arbetsgruppen bildades $i$ Sverige. Länskoderna finns i Figur 1. $Y=J a,-=N e j$.

\begin{tabular}{|c|c|c|c|c|c|c|c|c|c|}
\hline 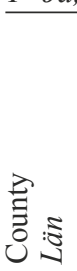 & 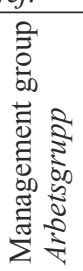 & 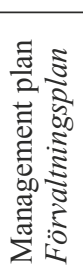 & 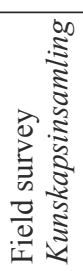 & 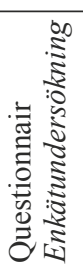 & 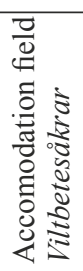 & 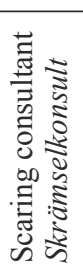 & 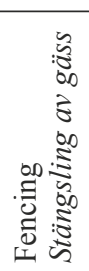 & 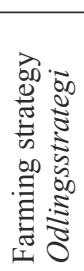 & 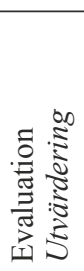 \\
\hline$\overline{\mathrm{AB}}$ & - & - & - & - & - & - & - & - & - \\
\hline C & - & - & - & - & - & - & - & - & - \\
\hline D & Y & - & $\mathrm{Y}$ & Y & - & - & $\mathrm{Y}$ & - & - \\
\hline $\mathrm{E}$ & Y & - & $\mathrm{Y}$ & Y & $\mathrm{Y}$ & $\mathrm{Y}$ & $\mathrm{Y}$ & $\mathrm{Y}$ & $\mathrm{Y}$ \\
\hline $\mathrm{F}$ & Y & Y & $\mathrm{Y}$ & - & $\mathrm{Y}$ & - & - & - & $\mathrm{Y}$ \\
\hline G & - & - & - & - & - & - & - & - & - \\
\hline $\mathrm{H}$ & Y & - & $\mathrm{Y}$ & Y & $\mathrm{Y}$ & - & - & Y & - \\
\hline I & Y & Y & $\mathrm{Y}$ & - & $\mathrm{Y}$ & Y & - & - & $\mathrm{Y}$ \\
\hline $\mathrm{K}$ & Y & - & - & - & - & - & - & - & - \\
\hline M & Y & $\mathrm{Y}$ & Y & - & $\mathrm{Y}$ & Y & Y & - & - \\
\hline $\mathrm{N}$ & - & - & - & - & - & - & - & - & - \\
\hline $\mathrm{O}$ & $\mathrm{Y}$ & - & Y & - & Y & - & Y & $\mathrm{Y}$ & Y \\
\hline S & Y & - & - & - & - & - & - & - & - \\
\hline $\mathrm{T}$ & $\mathrm{Y}$ & - & $\mathrm{Y}$ & - & $\mathrm{Y}$ & Y & Y & - & $\mathrm{Y}$ \\
\hline $\mathrm{U}$ & - & - & - & - & - & - & - & - & - \\
\hline W & $\mathrm{Y}$ & - & - & - & $\mathrm{Y}$ & $\mathrm{Y}$ & - & - & - \\
\hline X & - & - & - & - & - & - & - & - & - \\
\hline Y & - & - & - & - & - & - & - & - & - \\
\hline Z & - & - & - & - & - & - & - & - & - \\
\hline $\mathrm{AC}$ & - & - & - & - & - & - & - & - & - \\
\hline BD & - & - & - & - & - & - & - & - & - \\
\hline
\end{tabular}

the birds and whether measures taken to prevent crop damage on the initiative of the management groups are appreciated (Axelsson \& Modin 2006b, Administration board in county $\mathrm{H}$, unpubl. data).

\section{Implementing preventive measures}

Accomodation fields have been set off for geese and cranes in agricultural areas subjected to crop damage in eight of the Swedish counties since 2002 (Table 1). These fields vary in size between 5 and 20 ha and ranges in number between 1 and 6 depending on the size of the areas and the number of birds causing damage. At these fields, food is provided for the birds in various ways depending on which kind of birds one want to attract and during which time of the year the accommodation areas are supposed to be effective (e.g. Axelsson \&
Modin 2006a, Hake 2006). The effect of this measure on the movement patterns of birds has been evaluated for geese as well as for the Common Crane, which cause similar crop damage as geese, in five Swedish counties (Table 1). At lake Tåkern, Axelsson \& Modin (2006a) found that the geese and Cranes frequently used five accommodation fields, set off in the agricultural areas surrounding the lake, during most of the vegetation season. The proportion of geese and common cranes counted on these fields differed over time, but ranged between $20-60 \%$. Moreover, they found that fields bordering the accommodation fields received relatively few visits from grazing birds. At lake Kvismaren, between $80-100 \%$ of the common cranes present in the surrounding agricultural areas used an accommodation field set off during May-July 2005 (Hake 2006). Similarly, at lake Draven (Figure 1), 
Truvé (2006) found that a high proportion of the common cranes staging in the area used an accommodation field set off during 2006 as long as food was provided. The effective use of accommodation areas has earlier been shown in several studies (see Vickery \& Gill 1999 for a review). Thus, setting off accommodation fields seems to be an effective method to prevent crop damage by attracting birds to areas where they do not cause any damage. The accommodation areas reduce the possible risk of just moving the problem from one vulnerable field to another when the birds are scared from such fields, as they provide a refuge for the birds. However, setting off accommodation fields should preferably be combined with scaring of birds from fields with vulnerable crops, as this may make the accommodation areas even more preferred.

Scaring of birds can be done in numerous ways. To scare birds away from fields susceptible to damage caused by geese (see Conover 2002 for a review), the most commonly used methods in Sweden (e.g. Kjellander et al. 2002, Axelsson \& Modin 2006b) are propane cannons, "the Hulk" (an inflatable scarecrow that pops up from a box at irregular intervals), fireworks, wooden figures and flags. In five Swedish counties, one or more persons have been employed by the county administration boards as "scaring consultants" to help the farmers with scaring birds (Table 1). These persons may be contacted by the farmers when there is a risk of crop damage. They respond immediately and provide scaring devices or actively assist the farmers by scaring the birds and/or participating in protective hunting. Also, the "scaring consultants" normally have good knowledge of the movements of the birds and what kinds of crops that is grown within the local area. Thus, they can, on short notice, give priority to preventive measures which may minimize the damage, costs and conflicts between birds and farmers.

Fencing has been used in five of the Swedish counties. Specially designed fences have been put up to prevent crop damage made by geese close to breeding sites (Table 1). This measure is currently most extensively used at lake Tåkern, where about $11 \mathrm{~km}$ of such fence has been put up during the last five years (Karl-Martin Axelsson, pers. comm.). Quantitative evaluation of this method has not yet been conducted, but the general impression is that farmers growing crops close to breeding areas of Greylag and Barnacle Geese face less problems when fences are put up (County administration boards, pers. comm.). It is also interesting to note that after the fences were put up at lake Tåkern, the number of breeding Greylag Geese has decreased (Gezelius 2009), and less subsidies for crop damage caused by geese have been paid (Karl-Martin Axelsson, pers. comm.). However, a proper evaluation of this method should be prioritized in the future.

Farming strategy adjustment to prevent crop damage caused by grazing birds may be restricted by regulations on both a European and Swedish level and the farmers' need to use certain crop schemes on the fields e.g. to minimize the risk for pathogens and the use of fertilizers. However, adjustments in the farming strategy are regularly made in at least three of the Swedish counties (Table 1). A good example comes from lake Hornborga (Figure 1), where a farmer grows a special variety of barley on several fields. This variety grows fast and is possible to harvest 2-3 weeks before the conventional varieties. As a consequence, large areas of stubble fields appear early in the autumn, when geese and crane starts to aggregate in the area. The stubble fields then serve as accommodation areas for cranes and geese (e.g. Kjellander 2003, Axelsson 2004) during this period and hence prevent the birds to cause damage to vulnerable crops. This variety of barley produces a lower harvest than the conventional ones, but the financial loss is subsidized to the farmer by the county administration board.

\section{Evaluating the measures taken}

The measures implemented within the working model presented in this paper may be evaluated on different spatial and temporal scales. So far, evaluations have been made in five of the Swedish counties (Table 1), but only on a relatively small scale mainly concerning the change in numbers and behaviour of birds. Also, questionnaires have been sent out to evaluate how farmers in different areas experience the conflict with the birds and the preventive measures taken (e.g. Axelsson \& Modin 2006a). The information achieved has been adaptively implemented within the management plans produced by the management groups.

However, there are also needs for developing methods to evaluate measures taken at a larger scale, i.e. within the entire working model. This includes not only ecological aspects, i.e. the change in behaviour of birds, economical aspects, i.e. the economical losses of affected farmers, but also psychological aspects, e.g. how the "quality of life" is affected for the stakeholders involved. To develop such methods, there are several problems 
which must be dealt with. To evaluate the measures taken on an economical scale, it is important that all farmers report their damage. From questionnaires, we know that still relatively few farmers do so (Axelsson \& Modin 2006b). Therefore, it is difficult to evaluate the economical benefits, as we currently do not know how much "hidden" damage we may avoid by taking the preventive measures. Also, the psychological benefits are difficult to measure, as this aspect is rather vague and preferably measured through questionnaires and interviews with affected stakeholders. Thus, no good methods for performing a complete evaluation of the effectiveness of the working model are currently available, and it is of primary importance that the development of such methods is prioritized in the future.

\section{References}

Axelsson, K.-M. 2004. Habitatval hos tranor, gäss och sångsvanar kring Tåkern. Report 14, pp. 55. Linköping, Länsstyrelsen Östergötland. (In Swedish).

Axelsson, K.-M. \& Modin, T. 2006a. Lantbrukarnas syn på viltskador orsakade av gäss och tranor kring Tåkern. Report 29, pp. 10. Länstyrelsen i Östergötland. Linköping. (In Swedish).

Axelsson, K.-M. \& Modin, T. 2006b. Viltbetesåkrar, utfodringsplatser och skrämsel åtgärder för att förebygga viltskador av gäss och tranor vid Tåkern. Report 13, pp. 16. Länsstyrelsen Östergötland, Linköping. (In Swedish).

Conover, M. 2002. Resolving human-wildlife conflicts - the science of wildlife damage management. Lewis publishers, Boca Raton, USA.

Feige, N., van der Jeugd, P., van der Graaf, A.J., Larsson, K., Leito, A. \& Stahl, J. 2008. Newly established breeding sites of the Barnacle Goose Branta leucopsis in Northwestern Europe - an overview of breeding habitats and colony development. Vogelwelt 129: 244-252.

Fox, A.D., Ebbinge, B.S., Mitchell, C., Heinicke, T., Aarvak, T., Colhoun, K., Clausen, P., Dereliev, S., Faragó, S., Koffijberg, K., Kruckenberg, H., Loonen, M., Madsen, J., Mooij, J., Musil, P., Nilsson, L., Pihl, S., van der Jeugd, H. 2010. Current estimates of goose population sizes in the Western Palearctic, a gap analysis and assessment of trends. Ornis Svecica 20: 115-127.

Gezelius, L. 2009. Geese-counts. Pp 9-12 in Annual report 2008 from Tåkern Field Station, Sweden (Gezelius, L \& Nilsson, L., eds.). Linköping. (In Swedish).

Gordon, I.J. 2009. What is the future for wild, large herbivores in human-modified agricultural landscapes? Wildlife Biology 15: 1-9.

Hake, M. 2006. Fungerar tranåkrar? Fåglar i Kvismaren 21: 12-17. (In Swedish).

Jacobson, S.K. \& McDuff, M.D. 1998. Training Idiot Savants: The Lack of Human Dimensions in Conservation Biology. Conservation Biology 12: 263-267.

Jefferies, R.L., Rockwell, R.F. \& Abraham, K.E. 2004. Agricultural food subsidies, migratory connectivity and large- scale disturbance in arctic coastal systems: A case study. Integrative and Comparative Biology 44: 130-139.

Kjellander, P., Hake, M., Ahlqvist, I., Sjöstedt, E. \& Levin, M. 2003. Tranor vid Kvismaren - antalsvariationer, val av födosöksområden och skadeförebyggande åtgärder. Wildlife Damage Centre, report no. 1/2003.

Lorenzen, B. \& Madsen, J. 1986. Feeding by Geese on the Filso Farmland, Denmark, and the Effect of Grazing on Yield Structure of Spring Barley. Holarctic Ecology 9: 305-311.

McIvor, D.E. \& Conover, M.R. 1994. Perceptions of Farmers and Non-Farmers Toward Management of Problem Wildlife. Wildlife Society Bulletin 22: 212-219.

Nilsson, L. 2009 International waterfowl and goose counts in Sweden. Annual report 2008/09. Lund University. (In Swedish with English summary).

Olofsson, P. 2008. Flyginventering av grågås $i$ Hammarsjön och Araslövssjön samt delar av Oppmannasjön och Ivösjön. Vattenriket i fokus 2008:09, Biosfärkontoret Kristianstads Vattenrike, Kristianstads Kommun, Sweden (In Swedish)

Samelius, G. \& Alisauskas, R.T. 2009. Habitat alteration by geese at a large arctic goose colony: consequences for lemmings and voles. Canadian Journal of Zoology-Revue Canadienne de Zoologie 87: 95-101.

Summers, R.W. 1990. The Effect on Winter-Wheat of Grazing by Brent Geese Branta bernicla. Journal of Applied Ecology 27: 821-833.

Truvé, J. 2006. Tranors nyttjande av en tranbetesåker vid Draven $i$ Jönköpings län. Svensk Naturförvaltning rapport 22-2006. (in Swedish).

Truvé, J. 2008. Tranor och grågäss runt Draven - inventering på jordbruksmark. Svensk Naturförvaltning rapport 03-2008. (in Swedish).

Zacheis, A., Hupp, J.W. \& Ruess, R.W. 2001. Effects of migratory geese on plant communities of an Alaskan salt marsh. Journal of Ecology 89: 57-71.

\section{Sammanfattning}

Populationerna av flera gåsarter har ökat kraftigt såväl i Sverige som i övriga Europa under de senaste 10-15 åren. I Sverige visar årliga höst- och vinterräkningar att grågåsen Anser anser t.ex. har tiofaldigat sin populationsstorlek under perioden 1985-2009, från ca 20.000 till 225.000 ex. I nordvästra Europa har antalet övervintrande gäss under perioden 1995-2008 ökat med 24\%, från ca 3,5 till 4,3 miljoner individer. Detta har medfört att de skador fåglarna orsakar på kommersiellt odlade grödor genom avbetning och nedtrampning har ökat kraftigt. Enligt svensk lagstiftning skall skador som orsakas av vilt i första hand förebyggas genom jakt. När detta inte är möjligt, t.ex. om skadorna orsakas av fredade arter, skall skadorna förebyggas med andra metoder. Om skador uppstår trots att man har vidtagit förebyggande åtgärder, kan länsstyrelserna (Figur 1) söka statliga medel för att kompensera lantbrukarnas förluster. Länsstyrelserna kan även 
söka bidrag från staten för att vidta förebyggande åtgärder. Därigenom kan konflikterna mellan betande fåglar och lantbrukare mildras. 2008 betalade staten ut 4,9 miljoner i bidrag till förebyggande åtgärder och ersättning för skador på gröda (Figur 2). Förutom ekonomiska konsekvenser kan skadorna även medföra att acceptansen minskar för åtgärder som kan gynna den biologiska mångfalden, t.ex. restaurering av våtmarker och bildande av naturreservat. Det är därför viktigt att konflikterna mildras även ur ett naturvårdsperspektiv.

Viltskadecenter är en myndighet som arbetar på uppdrag av Naturvårdsverket. Centret har till uppgift att underlätta arbetet med att förebygga konflikter mellan fredade djur och människan, och har, under de senaste åren, utvecklat en arbetsmodell för att dämpa konflikterna mellan lantbrukare och fredade fåglar i jordbruksområden. Vi redovisar här de olika åtgärder som ingår i denna modell och diskuterar hur effektiva de är och kan bli på sikt. Arbetsmodellen bygger på fyra steg som bör tas i tur och ordning:

\section{Bilda en arbetsgrupp med representanter från berörda intressegrupper}

Arbetsgruppen bör bestå av representanter från alla intressegrupper som berörs av konflikten (se exempel i Figur 3). Vidare bör gruppen ha regelbundna möten där man upprättar och vidareutvecklar en förvaltningsplan som syftar till att minska konflikterna i det aktuella området.

\section{Samla in information om fäglarnas beteende och skademönster}

För att kunna vidta kostnadseffektiva skadeförebyggande åtgärder behöver man samla in grundläggande information om fåglarnas beteende och hur skadorna varierar i tid och rum. Detta kan man göra t.ex. genom fältstudier av de skadegörande fåglarnas antal och utbredning och genom att undersöka vilka kunskaper som finns lokalt om skadorna och fåglarnas beteende hos lantbrukare och ornitologer.

\section{Vidta förebyggande åtgärder}

Den information man har fått genom fältstudier och övrig kunskapsinsamling skall ligga till grund för att vägleda skadeförebyggande åtgärder. I det förebyggande arbetet är det fyra åtgärder som är speciellt viktiga att jobba med.

Avsätt viltåkrar. Avsätt åkrar på vilka fåglarna kan söka föda ostört. Dessa fält måste anläggas i områden där man vet att gässen tycker om att vistas. Åkrarna skall göras så attraktiva som möjligt genom att man odlar grödor som fåglarna tycker om. Man kan även utfodra fåglarna på viltåkrarna under perioder då det är särskilt stor risk för att skador skall uppstå.

Skrämsel. Skräm fåglarna från känsliga fält till de avsatta viltåkrarna med hjälp av lämpliga skrämselanordningar och skyddsjakt. Om risken för skador är stor, anställ resurspersoner som kan rycka ut med kort varsel och hjälpa drabbade lantbrukare med skrämseln och skyddsjakten.

Stängsling. I områden där odlingsmark gränsar till lämplig häckningsbiotop för gäss kan det vara nödvändigt att sätta upp speciella stängsel för att hindra häckande och ruggande gäss från att gå upp och beta på fält med skadekänslig gröda.

Odlingsstrategi. Anpassa, om möjligt, odlingsstrategin i det aktuella området så att risken för skador minimeras. Man kan t.ex. odla grödor som gässen inte tycker om och/eller odla skadekänsliga grödor i områden där gässen inte tycker om att vistas pga. mänsklig aktivitet.

\section{Utvärdera effekten av vidtagna åtgärder}

För att utveckla och förbättra de förebyggande åtgärder som vidtas, måste de använda metodernas effektivitet utvärderas. Detta kan man t.ex. göra genom att följa upp förändringar i de skadegörande fåglarnas antal och beteende, skadefrekvens, ekonomiska kostnader och attityder hos människor som är berörda av konflikterna.

\section{Resultat och diskussion}

Sedan 2002 har 12 arbetsgrupper i 11 län upprättats på initiativ av respektive länsstyrelse (Tabell 1). Detta har ökat förståelsen och kommunikationen mellan olika intressegrupper och bidragit till att skapa ett mer positivt klimat i arbetet för att hantera skadeproblematiken. Arbetsgrupperna har dessutom initierat kunskapsinsamling angående fåglarnas beteende och skadornas utbredning genom fältstudier och sammanställning av befintliga kunskaper hos berörda parter genom frågeenkäter. I tre län har även förvaltningsplaner upprättats (Tabell 1).

En rad olika skadeförebyggande åtgärder har vidtagits på initiativ av grupperna. En kombination av skrämsel och avsättning av viltåkrar har visat sig vara speciellt effektiv för att styra fåglarna till områden där de inte orsakar några skador. I vissa "högriskområden" har länsstyrelsen anställt resurs- 
personer som hjälper lantbrukarna med skrämsel och skyddsjakt (Tabell 1). Kunskapsinsamlingen har även gett tips om var man skall sätta upp stängsel för att förhindra häckande och ruggande gäss att gå upp och beta på åkrar som angränsar till områden med lämplig häckningsbiotop för gässen (Tabell 1).

För att öka förståelsen för viltförvaltning rent allmänt är det viktigt att allmänheten kan få information om och möjlighet att påverka de beslut som tas. Arbetsgrupperna bjuder därför in allmänheten till årliga möten, vid vilka alla som närvarar kan få delge sina synpunkter på de skadeförebyggande åtgärder man vidtagit och de resultat man har uppnått.
Om man skall kunna utveckla förvaltningsarbetet $\mathrm{i}$ framtiden måste man utvärdera effekterna av de skadeförebyggande åtgärder som vidtagits. Sådana utvärderingar har hittills gjorts på en liten rumslig skala. Man har exempelvis gjort utvärderingar av hur avsättningen av viltåkrar i kombination med skrämsel påverkar de skadegörande fåglarnas beteende (Tabell 1). Däremot har man ännu inte gjort utvärderingar på en större rumslig skala, t.ex. av hur de förebyggande åtgärderna som har vidtagits påverkat skadefrekvens, ekonomi och de människor som påverkas totalt sett. Sådana utvärderingar är svårare att göra, och en utveckling av metoder för att analysera detta måste prioriteras $\mathrm{i}$ framtiden. 